\title{
ПРИНЦИПИ НАВЧАННЯ ФОНЕТИКИ УКРАЇНСЬКОЇ МОВИ
}

Бакум 3. П. Принципи навчання фонетики української мови.

У статті визначено сучасні принципи навчання фонетики на етапі поглиблення, узагальнення та систематизації знань з української мови, обгрунтовано особливості реалізації загальнодидактичних, лінгводидактичних та специфічних принципів з урахуванням провідних підходів навчання. Виокремлено принцип текстоцентризму, особливість якого полягає у вивченні української мови на основі тексту.

Ключові слова: принципи навчання української мови, загальнодидактичні принципи, лінгводидактичні принципи, специфічні принципи, принцип текстоцентризму.

Бакум 3. П. Принципы обучения фонетике украинского языка.

В статье определены современные принципы обучения фонетике на этапе углубления, обобщения и систематизации знаний по украинскому языку, обосновано особенности реализации общедидактических, лингводидактических и специфических принципов с учетом основных подходов обучения. Выделено принцип текстоцентризма, особенность которого заключается в обучении украинского языка на текстовой основе.

Ключевые слова: принципы обучения украинскому языку, общедидактические принципы, лингводидактические принципы, специфические принципы, принцип тестоцентризма.

Bakum Z. P. The principles of studying phonetics of the Ukrainian language.

The article deals with modern principles of studying phonetics on the stage of generalization, deepening and systematization of knowledge of the Ukrainian language. The author grounds peculiarities of realization of general didactic principles, linguistic didactic principles and specific principles taking into account main approaches in teaching. The principle of textin-the-centre is described: studying of Ukrainian is based on the text.

Key words: principles of studying the Ukrainian language, general didactic principles, linguistic didactic principles, specific principles, a text-in-the-centre principle.

Освітній процес характеризують ті чи ті принципи, що зумовлюють пріоритетні особливості навчання, детермінують його зміст, уможливлюють доцільний вибір методів і прийомів. Підходи відрізняються один від одного не стільки різноманітним набором принципів, скільки реалізацією в певній системі навчання. Тому вагомим чинником ефективності методичної системи є правильно визначені принципи, частина яких, на жаль, для вчителів-практиків, як констатує О. Горошкіна, нині поки що „залишаються декларацією, але такою, що чекає наповнення”, окрім того, „творчі педагоги добре розуміють цінність таких підходів до навчання рідної мови й активно впроваджують їх у свою практику" [1, 82]. 
Сучасні розвідки в царині методики навчання мови грунтуються передовсім на дидактичних принципах, спільних для всіх шкільних предметів, - „системі вихідних положень, які визначають зміст, організаційні форми та методи навчальної роботи відповідно до загальної мети виховання i закономірностей процесу навчання" [7,55]. Учені (М. Данилов, В. Онищук, М. Скаткін, К. Ушинський, С. Чавдаров), розв'язуючи проблеми дидактичних принципів, у всі часи виходили з необхідності раціонального використання цінного і прогресивного з вітчизняної та зарубіжної педагогіки. За результатами наукових досліджень можна виокремити загальну систему принципів навчання, роль якої важко переоцінити в нашій розвідці: науковості; зв'язку теорії з практикою; систематичності й послідовності, свідомості та активності; наочності в навчанні; міцності засвоєння знань, набуття вмінь та навичок, доступності навчання; урахування індивідуальних особливостей учнів у колективній роботі; гуманізації та демократизації й т. ін.

Не менш „правильними й надійними” в навчанні мови, за словами I. Олійника, є лінгводидактичні принципи [6, 47], проаналізовані в працях О. Біляєва, Є. Голобородько, Є. Дмитровського, В. Масальського, М. Пентилюк, К. Плиско, О. Текучова, Л. Федоренко. Названі принципи притаманні конкретному предмету, передбачають розуміння мовних значень, розвиток лексичних і граматичних навичок, розвивають увагу до виразних засобів мовлення, зіставлення писемної форми мовлення 3 усною (Л. Федоренко); визнають взаємозалежність між вивченням мови й розвитком мислення, вивченням граматики та формуванням мовленнєвих навичок (О. Текучов).

Важливо в теорії та практиці навчання гімназійного курсу фонетики реалізовувати принципи стратегічного (активізація розвивального впливу думки на мовлення і навпаки; пріоритетність комунікативної функції мови й необхідність комунікативного спрямування в навчанні; розкриття естетичної функції мови і формування естетичних відчуттів та смаків у школярів) і тактичного характеру (надання переваги індукції як способу мислення, що активно забезпечує засвоєння мовних явищ та категорій; дотримання міжрівневих зв'язків у навчанні мови; опора на одиниці мовлення під час вивчення мовних явищ і на одиниці мови під час опрацювання різних жанрів мовлення), запропоновані О. Дудниковим. Критеріями стратегічних принципів методики є соціально-психологічні функції мови, а для формулювання методичних принципів тактичного призначення - чинники структурно-лінгвістичної специфіки мови [3, 13-18].

Певний інтерес для науковців та вчителів-словесників становлять принципи навчання мови, розроблені К. Плиско: пізнавально-практична спрямованість навчання мови, комунікативна та функційно-стилістична спрямованість навчання мови, вивчення мови у структурній цілісності, 3 обов'язковим пізнанням їі рівнів; вивчення мовних явищ у єдності форми і 
змісту (структури), семантика та функціонування; вивчення мови в міжрівневих, внутрішньорівневих і міжпредметних зв'язках; активізація взаємовпливу навчання мови й розвитку мислення та мовлення; використання мовленнєвої практики для засвоєння теорії мови й, навпаки, - теорії мови для розвитку мислення [8].

По-своєму, дещо оригінально, власне методичні принципи тлумачить Т. Донченко, наголошуючи на тому, що вони випливають із соціальної значущості та соціально-психологічних функцій мови: відображення в мові духовного багатства народу, його національної самоідентифікації, самосвідомості, моралі, переконань, способу мислення, культури, духовності; здатність мови бути засобом пізнання світу; мислетворча функція мови; конструктивна функція; комунікативна сутність мови як засобу спілкування; естетична функція мови як форми і засобу творення художньої специфіки літературного твору $[2,2]$.

До методичних Л. Федоренко відносить принципи, особливо важливі для навчання фонетики: уваги до матерії мови (його реалізація сприяє розвитку вміння чути особливості вимови, відпрацюванню рухів мовленнєвого апарату, необхідних для вимови звуків мови); розуміння мовних явищ (уможливлює розділити у свідомості саму мову і те, що з іï допомогою можна висловити); оцінки виразності мовлення (передбачає розвиток в учнів уміння чути, оцінювати милозвучність, виразність поетичного твору, уловлювати на слух рими та ін.); розвитку чуття мови (полягає у свідомому засвоєнні учням норм літературної мови, їхнього дотримання) [10, 18-30].

За науково-методичну основу в навчанні гімназійного курсу фонетики доцільно обрати сучасну теорію принципів засвоєння рідної мови, що забезпечує процес формування мовної, мовленнєвої, комунікативної та соціокультурної компетенцій учнів, запропоновану М. Пентилюк, яка виокремлює загальнодидактичні принципи навчання української мови (традиційні: науковість, систематичність, послідовність, наступність, перспективність, зв'язок теорії з практикою, наочність, доступність, зв’язок навчання з вихованням; сучасні: гуманізація, гуманітаризація, єдність національного й загальнолюдського, розвивальний характер навчання, співтворчість, індивідуалізація і диференціація, оптимізація) та лінгводидактичні (загальнометодичні: взаємозалежність мови і мислення, екстралінгвістичний, функційний, міжпредметного та внутрішньопредметного зв'язку, зв'язок навчання двох (кількох) мов, нормативно-стилістичний, історичний, взаємозалежність усного і писемного мовлення; специфічні (рівневі): зв'язок вивчення мови 3 мовленнєвою діяльністю, вивчення мови на синтаксичній основі, зв'язок навчання пунктуації та виразного читання, зіставлення звуків і букв, лексико-синтаксичний, структурно-семантичний, структурнословотвірний, парадигматичний, інтонаційний) [9, 47].

Загальнометодичні принципи ,зобов’язують так добирати методи навчання, щоб привертати увагу школярів до звучання мовних одиниць і мо- 
влення, забезпечувати тренування органів мовлення, навантажувати інтелектуальною роботою, виробляти увагу до виразових засобів мовлення, активізувати роботу пам'яті, випереджено розвивати усне мовлення, тренувати у визначенні співвідношень між звуковим та графічним образами мовних одиниць” $[6,155]$.

До загальнометодичних принципів пропонуємо додати ще й навчання фонетики на текстовій основі, або текстоцентричний принцип, який передбачає визнання тексту як найважливішої одиниці в навчанні рідної мови. Адже в контексті реалізується семантика мовних одиниць усіх рівнів, зокрема фонетики. У зв'язку з цим М. Львов зазначає, що контекст сам не народжує будь-якого значення мовної одиниці; він лише реалізує, дає статус функціонування справжнього значення мовної одиниці [5, 86; 206-207].

Текстоцентричний принцип у навчанні фонетики може реалізовуватися в таких напрямках: текст є засобом пізнання мови як поліфункційного явища; текст виступає найважливішим засобом долучення до української культури; навчання фонетики здійснюється на основі тексту як одиниці мови, завдяки якій відбувається пізнання фонетичних явищ та засобів, формується система фонетичних понять; текст виступає як мовленнєвий витвір, результат використання системи мови, оскільки на його засадах вивчається мова в діiі, засвоюються закономірності функціонування фонетичних засобів у мовленні; текст - основний засіб оволодіння усними та писемними формами українського мовлення, оволодіння мовленнєвою діяльністю у всіх іiї видах (читання, говоріння, аудіювання, письмо), на його основі формується комунікативна компетенція; текст є засобом створення ситуацій, на основі яких здійснюється реальне спілкування.

Прийнято вважати, що теоретична розробка текстоцентричного принципу в навчанні мови започаткована в $60-70$-х роках минулого століття, коли до складових зв'язного мовлення Т. Ладиженською було введено не лише мовленнєву діяльність, але й результат акту комунікації, певний мовленнєвий витвір, текст.

Нами вже відзначалося, що текст є засобом пізнання мови як поліфункційого явища, адже вона за своєю природою дійсно різноаспектна i виконує немало функцій: комунікативну, репрезентативну, апелятивну, експресивну, впливу, емотивну, поетичну, фактичну, концептуальну, оцінно-комунікативну, текстову, експресивну, естетичну, номінативну, синтаксичну і прагматичну, когнітивну.

У лінгводидактиці тривалий час зосереджувалася увага на мові як знарядді пізнання. Однак останнім часом з урахуванням функцій феномену мови в методичній науці та практиці відбувається перегляд усталених підходів, принципів і обирається курс на усвідомлення мови як поліфункціонального явища, завдяки якому відбувається спілкування, регулюються міжособистісні й соціальні стосунки людей, координується практична діяльність, формується свідомість, самосвідомість і світогляд особистості. 
Важливим у реалізації текстоцентричного принципу є положення про те, що текст виступає засобом долучення учнів до матеріальної та духовної культури украӥнського народу, його історії, звичаїв і традицій. Адже національно-культурний компонент в навчанні рідної мови стає одним із найважливіших засобів розвитку духовного світу школяра, його ціннісно-орієнтаційної культури, національної самосвідомості, врештірешт української мовної особистості. Тому теоретики і практики сьогодні перебувають у пошуках такого текстового матеріалу, який сприятиме вихованню особистості як творця, носія, користувача мови з іiї історико-, етно-, соціо-, психолінгвістичними особливостями.

Навчання повинне відбуватися також і на основі тексту як одиниці мови, завдяки якій пізнаються мовні явища та засоби, формується система мовних понять. Знайомство з подібними текстами сприяе тому, щоб учні входили у світ науково-навчальної інформації, ознайомлювалися 3 логікою побудови тексту, збагачувалися науковою лексикою і відповідними синтаксичними конструкціями; навчалися осмислено, інтонаційно грамотно читати та ін.

Текст виступає також і як мовленнєвий витвір, результат використання мови, оскільки на його основі здійснюється вивчення мови в діiі, засвоюються закономірності функціонування фонетичних, лексичних засобів у мовленні. Наприклад, Прочитайте виразно текст T. Ніколаєвої. Підготуйте повідомлення „Інтонація та емоції людини”. Безсумнівно, щзо інтоначія пов'язана з вираженням емочій людини. За допомогою інтонаиії висловленню можна надавати різноманітних емоційних відтінків, тобто в інтоначії є емочія, яка завжди відображає стан мовия або його бажання певним чином подіяти на мовия. Чітко виділяють дві групи емоцій (позитивні - задоволення, радість, захоплення; негативні - невдоволення, гнів, роздратування). Емоційність висловлення залежить від екстралінгвістичного чинника, що створює в мовия або слухача певний емоизйний настрій. За цієё умови одне й те ж висловлення може нести різний емоиійний настрій, проте емоиії не впливають на комунікативну установку висловлення. Так, наприклад, незалежно від того, з радістю чи з сумом буде сказано: Він залишився, - основне комунікативне значення - повідомлення інформації - буде незмінним.

Завдяки тексту стає можливим синтез, поєднання двох важливих напрямків у навчанні: пізнання системи мови й оволодіння нормами мовленнєвої поведінки.

Текст с одним із основних засобів оволодіння усними та писемними формами украӥнського мовлення, мовленнєвою діяльністю у всіх іiі видах (читання, говоріння, аудіювання, письмо). На текстовій основі формується комунікативна компетенція, у процесі розвитку якої мовленнєвознавча теорія засвоюється учнями не у вигляді певних понять, правил, а в діяльнісній формі, у вигляді вмінь, навчальних дій з цими поняттями і пра- 
вилами. До них можна віднести вміння визначати стиль тексту, тип мовлення, спосіб зв'язку речень у тексті, стилістичний аналіз та ін. Таким чином, під час формування уявлень про особливості побудови того чи того тексту є можливість вчити школяра створювати власне висловлювання.

Неабияку роль у навчанні мови посідає імітаційне моделювання ситуацій, завдяки чому учень потрапляє в умови, наближені до життєвих. За таких обставин навчання здійснюється через зразки монологічного й діалогічного мовлення, а текст є засобом створення ситуацій, на основі яких здійснюеться реальне спілкування.

Певну вагу становлять також специфічні принципи навчання, оскільки кожен розділ науки про мову має свою особливість. Актуальним із цього погляду залишається положення I. Олійника про реалізацію специфічних принципів у навчанні фонетики: 1) спиратися на усне мовлення учнів і виробляти в них увагу до мовлення, що відповідає літературним нормам; 2) удосконалювати вміння артикулювати звуки української мови; 3) поєднувати імітаційний шлях засвоєння орфоепічних навичок із свідомим засвоєнням норм літературного мовлення; 4) спиратися на мовний слух, удосконалювати слухову пам'ять; 5) постійно тренувати в зіставленні звукової оболонки слів, а також інтонаційної структури речень із їх графічною формою $[6,155]$.

Окрім названих принципів, що усталилися в методиці фонетики, пропонуємо реалізовувати ще й принцип навчання фонетики у взаємозв'язку з орфоепією, графікою, орфографією, морфологією, синтаксисом, пункmуацісю. Узагальнення фонетичних знань не повинно проходити ізольовано від вивчення орфоепії, граматики, орфографії, стилістики. Навпаки, вивчаючи граматичне і лексичне значення слів, необхідно йти від їх фонетичної (звукової) структури, оскільки фонетична форма слова за своєю природою первинна. Ця ідея і раніше підтримувалася в методичній науці: „Мовлення дитини у своєму індивідуальному розвитку йде від засвоєння матерії мови (фонетики - фонем і просодем) до засвоєння лексики і граматики” $[6,49]$. Більше того, „чи не найтоншою матерією кожної мови $є$ ii фонетична структура, вона найбільше піддається ерозіі” [4, 22].

Поряд із названим принципом варто розглянути принцип аналізу зву$\boldsymbol{\kappa} \boldsymbol{a}$ в морфемі, реалізація якого сприяє розумінню учнями змін залежно від позиції чергувань сильних і слабких звуків. Такі спостереження створюють теоретичне підгрунтя для роботи над буквеними орфограмами.

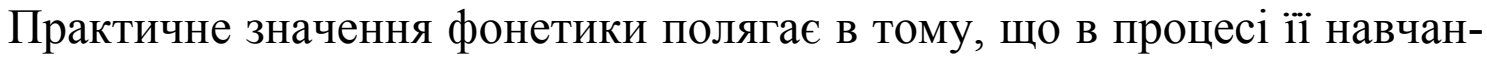
ня учні оволодівають орфоепічними й орфографічними нормами української літературної мови. Тому є потреба у виокремленні принципу сnіввідношення між звуковим та писемним мовленням, дотримання якого дасть змогу учневі усвідомити роль звуків як засобу виразності мовлення, сприятиме підвищенню загальної культури мовлення учнів, глибокого сприймання текстів художньої літератури. 
У навчанні фонетики доцільно, як показало дослідження, керуватися принципом урахування особливостей місцевої говірки, адже значна частина відхилень від норм сучасної української літературної мови спричинена впливом навколишнього мовленнєвого середовища, передовсім діалектного. У процесі експериментальної роботи, наприклад, під час пояснення особливостей передачі на письмі дзвінких приголосних ми побачили, що словесники майже не зосереджують увагу на орфоепічній властивості уникнення оглушень звуків у кінці слова і складу, а відразу шукають слова для перевірки.

Реалізація принципу фізичного розвитку органів мовлення націлює на засвоєння учнем кожної морфеми, опанування вимови комплексу звуків, інтонаційних особливостей синтаксичних конструкцій, водночас викликає необхідність тренувань органів мовлення, удосконалення вимовних навичок. Л. Федоренко наголошує, що це правило зобов'язує вчителя „добирати такі засоби навчання, які допомагають йому спрямовувати природний процес засвоєння мовлення закономірним шляхом, забезпечуючи звукову i зорову наочність, оптимальність тренувань органів мовлення" $[10,21]$. Тренування мовленнєвих органів уможливлює і свідоме розмежування голосних та приголосних звуків, а не їх механічне запам'ятовування. Досягти цього можна лише тоді, коли учень матиме уявлення про органи мовлення. Адже звуки людського мовлення відрізняються від суто фізичних звуків насамперед тим, що вони є фізіологічним явищем. Фонетика, хоч і послуговується дослідженнями анатомії та фізіології органів мовлення, усе ж створює власну анатомію і фізіологію відповідно до тих особливостей органів, які мають значення лише для творення звука. Мовознавці, учителі-словесники говорять про частини язика, про вібрацію певних органів, утворення щілин між певними органами - усе це не $\epsilon$ предметом розгляду фізіології.

Отже, загальнодидактичні, лінгводидактичні та специфічні принципи виражають закономірність процесу навчання, а їх дотримання - необхідна умова успіху професійної діяльності вчителя. Подані вище принципи тісно пов'язані між собою. Недотримання хоч би одного з них ускладнить реалізацію інших, призведе до зниження загальної ефективності навчання.

\section{Література}

1. Горошкіна О. М. Лінгводидактичні засади навчання української мови в старших класах природничо-математичного профілю : монографія / Олена Миколаївна Горошкіна. - Луганськ : Альма-матер, 2004. - 362 с.

2. Донченко Т. Власне методичні принципи навчання української мови Т. Донченко // Українська мова і література в школі. - 2004. - № 2. - С. 2-4.

3. Дудников А. В. О стратегических и тактических принципах методики преподавания русского языка / А. В. Дудников // Русский язык в школе. - 1974. № 3. - C. 13-18.

4. Захарків О. Твоє мовне обличчя. Яке воно? / О. Захарків // Урок української. 2003. - № 3. - С. 22-23.

5. Львов М. Р. Словарь-справочник по методике русского языка / Михаил Ростиславович Львов. - М. : Просвещение, 1988. - 240 с. 
6. Методика викладання української мови в середній школі : навч. посіб. / I. С. Олійник, В. К. Іваненко, Л. П. Рожило, О. С. Скорик ; за ред. I. С. Олійника. - 2-ге вид., перероб. і доп. - К. : Вища школа, 1989. - 439 с.

7. Олійник П. М. Дидактичні принципи навчання та їх дидактико-методичні особливості / П. М. Олійник // Методика навчання і наукових досліджень у вищій школі / С. У. Гончаренко, П. М. Олійник, В. К. Федорченко та ін. ; за ред. С. У. Гончаренка, П. М. Олійника. - К. : Вища школа, 2003. - С. 55-68.

8. Плиско К. М. Лінгводидактичні основи організації навчання української мови в загальноосвітній школі : автореф. дис. на здобуття наук. ступеня д-ра пед. наук : спец. 13.00.02 „Теорія і методика навчання (українська мова)” / К. М. Плиско. - К., 1997. - 51 с.

9. Практикум з методики навчання української мови в загальноосвітніх закладах / С. О. Караман, О. В. Караман, О. М. Горошкіна та ін. ; за ред. М. І. Пентилюк. - К. : Ленвіт, 2003. - 302 с.

10. Федоренко Л. П. Принципы обучения русскому языку / Лидия Прокофьевна Федоренко. - М. : Просвещение, 1973. - 160 с. 